\title{
Improving yield and quality characteristics of kaffir lime oil (citrus hystrix $D C$ ) by solid fermentation pretreatment using tempeh yeast
}

\author{
Vivi Nurhadianty, Aji Hendra Sarosa, Ida Wahyuningsih, Chandrawati Cahyani* \\ Chemical Engineering Department, Engineering Faculty, Brawijaya University, J. Mayjen Haryono 167, Malang, Indonesia
}

* Corresponding author: ccahyani@yahoo.com

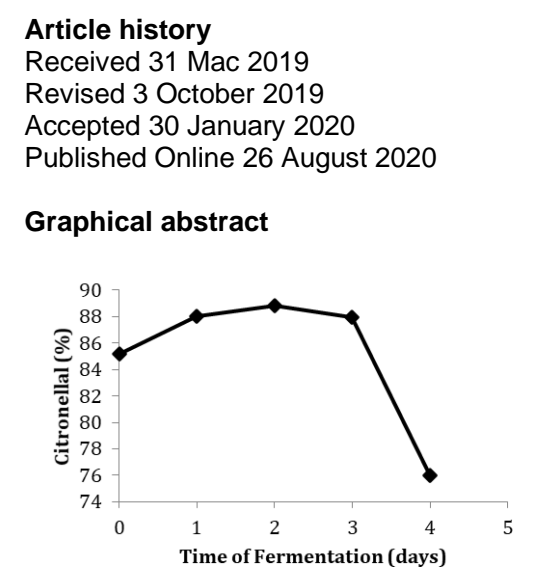

Accepted 30 January 2020

2020

\begin{abstract}
The industrial development of flavor and fragrance currently leads to natural ingredients. Kaffir lime is a potential ingredient developed from Indonesia, but distillation of essential oil in Indonesia generally results in low yields and quality. Fermentation as the initial treatment of distillation would improve the yield and quality of essential oil. The fermentation process is usually performed as pretreatment using cellulolytic bacteria such as Trichoderma harzianum, Trichoderma viride, or Trichoderma reesei, but the use of those bacteria is considered less practical for essential oil distillation process. Therefore, this research utilized tempeh yeast to increase yield and quality of essential oil. Since tempeh yeast consists of Rhizopus producing hyphae, it is expected that hyphae are able to penetrate the tissue, making it easier for oil to get out of the leaves. The aerobic fermentation process was carried out by continuous addition of air inside the fermenter with air compressor. Fermentation was observed within four days. The distillation was performed by using steam distillation method. The result of this study showed that leaf lime essential oil with fermentation process of day 3 produced the highest yield of $0.67 \%$, which increased $20 \%$ compared to nonfermented leaves. The composition of leaf lime essential oil was $87.92 \%$ Citronellal, $1 \% \beta$ caryophyllene, $0.3 \%$ Citronellal acetate, $0.9 \%$ Citronellol, and $1.77 \%$ linalool, which comply to local industry standard.
\end{abstract}

Keywords: essential oil, kaffir lime, fermentation

() 2020 Penerbit UTM Press. All rights reserved

\section{INTRODUCTION}

Consumers' preference towards natural products pave an opportunity for the essential oil industry. One of the essential oil products which possess great potential to be developed in Indonesia is kaffir lime (Citrus hystrix DC). The essential oil of kaffir lime leaves contains 57 types of chemical components such as $81.49 \%$ citronellal, $8.22 \%$ citronellol, $3.69 \%$ linalool, $0.31 \%$ geraniol, and other trace components (Susilo, 2016). The main component of kaffir lime is citronellal and flavor of kaffir lime leaves is derived from this component. High citronellal content in essential oil can be used as soap deodorizer, high-value perfume, liniment, toothpaste, and mouthwash (Ketaren, 1993). Its vast applications are due tto citronellal's beneficial properties such as antioxidant ( $\mathrm{Lu}$ et al., 2014) and antibacterial activities (Lopez-Romero et al., 2015).

According to a previous research, the yield of essential oil of kaffir lime leaves was around 0.47-0.88 \%, depending on the method used (Sato et al., 2011; Ririn et al., 2010; Mayasari, et al. 2013). The rapid development of essential oils in the world of trade has made pretreatment necessary to improve the yield and the quality of essential oil. Through pretreatment of kaffir lime leaves such as curing, drying, slicing, and PEF, kaffir lime oil produced ranged from 0.867-0.964\% has been reported (Khasanah et al., 2015; Axnessy et al., 2014; Endarta, 2008; Imron, 2008).

Another pretreatment method of kaffir lime leaf is fermentation. According to Raharjo and Retnowati (2012), this process degrades the cell wall components tissue, and require the help of microorganisms as a source of enzymes both natural and added microorganisms. Pretreatment using enzymes for the production of high-quality functional products from tomato processing waste has done by Zuorro et al. (2014). The enzymes have high activity in solid state fermentation (Masutti, 2012). The fermentation process is usually performed as pretreatment using cellulolytic bacteria such as Trichoderma harzianum, Trichoderma viride, or Trichoderma reesei but the use of those bacteria is considered less practical for essential oil distillation process. However, cellulolytic bacteria are difficult to get on the market.

To solve this, tempeh yeast was chosen as an alternative as a fermentation agent that was easily available on the market. Solid fermentation with the addition of tempeh yeast was able to increase the characteristics of physical quality and the yield of essential oil of citrus sweet peel waste (Laurita and Herawati, 2016). The result of the research showed that solid fermentation had a positive effect on the yield, with the highest yield $0.42 \%$ for a duration of 6 days of fermentation. Meanwhile, Khasanah et al. (2014) conducted preliminary treatment (fresh, solid fermentation, and liquid fermentation) with the addition of tempeh yeast to the yield and quality characteristics of cinnamon leaf essential oil. The results showed that fermentation time had a good effect on yield, with the best fermentation time on solid or liquid fermentation was on the fourth day yielding the highest yield of $0.14 \%$. The purpose of this research is to determine the effect of fermentation with the addition of tempeh yeast to the yield and the composition of the essential oil of lime leaves (Citrus hystrix DC). 


\section{EXPERIMENTAL}

\section{Materials}

Kaffir lime leaf was the main material in this study and it was obtained from Institute of Essential Oils, University of Brawijaya. Tempeh yeast as supporting materials was purchased from Indonesian Institute of Research (LIPI) with brand RAPRIMA.

\section{Fermentation Process}

The leaves $4 \mathrm{~kg}$ were fed into fermenter with the addition of $2 \%$ tempeh yeast powder as fermented agent. The fermentation process was carried out for $0,1,2,3$, and 4 days. Fermenter used was in the form of Styrofoam box. The aerobic fermentation process was performed under continuous addition of air inside the fermenter with air compressor. Air enters through the bottom of the fermenter with volumetric rate $0.4 \mathrm{~L} / \mathrm{s}$, then passes through the air cavity between the solid substrate and exits at the hole at the top of the fermenter. Design fermenter is shown in Fig. 1.

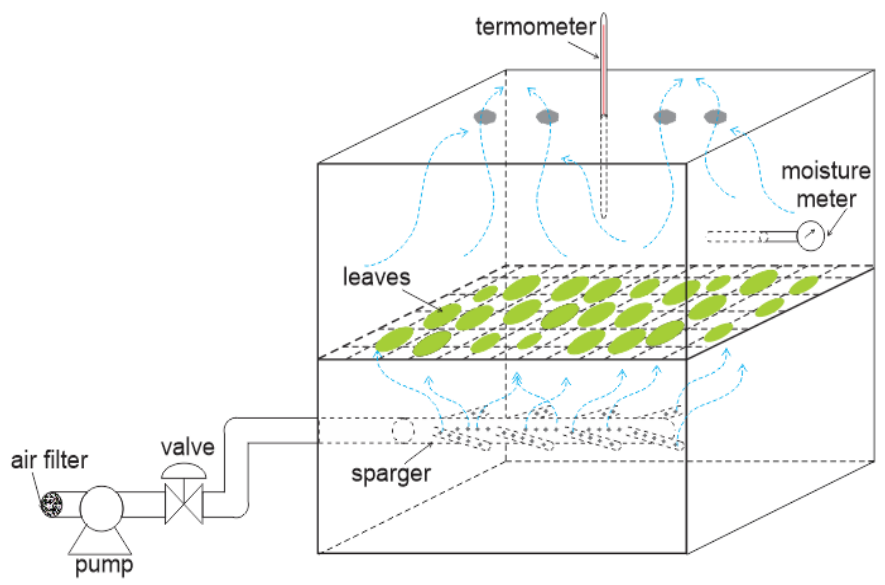

Fig. 1 Design of fermenter.

\section{Distillation of kaffir lime leaves}

The process of distillation of essential oil of kaffir lime leaves was done by using water-steam distillation method. This experiment used water-steam distillation equipment from Laboratory of Bioprocess Engineering, Brawijaya University. Both fermented and unfermented leaves were inserted into the distilled boiler. When water boils, moisture surround the leaves of kaffir lime and caused the oil components in the leaves to evaporate. Water vapor and kaffir lime leave oil were condensed until they liquified. The distillation process was carried out for 6 hours.

\section{Separation and purification of essential oils}

Distillate is a mixture of water and lime leaves oil. This distillate was moved to the separating funnel and separated during 24 hours. The separated oil was purified with anhydrous $\mathrm{Na}_{2} \mathrm{SO}_{4}$ (obtained from Laboratory of Bioprocess Engineering). The purpose was to remove all the residue-water in kaffir lime oil.

\section{Analysis}

The components of kaffir lime oil were identified by Gas Chromatography-Mass Spectrometry (GC-MS). The column type of GC-MS was RTX-5MS column. The carrier gas was helium. The column temperature was $60{ }^{\circ} \mathrm{C}$. The temperature of GC-MS injector was $240{ }^{\circ} \mathrm{C}$ and pressure was $100 \mathrm{kPa}$. The column flow rate was 1.61 $\mathrm{mL} / \mathrm{min}$ and total flow rate was $50 \mathrm{~mL} / \mathrm{min}$. The yield of process was calculated using Eq. (1).

$$
\% \text { improving yield }=\frac{\text { yield in } t_{n}}{\text { yield in } t_{0}} \times 100 \%
$$

where Yield in $t_{n}=$ Yield distillation with fermentation in $n$ days; Yield in $\mathrm{t}_{0}=$ Yield distillation without fermentation pretreatment ( 0 day).

\section{RESULTS AND DISCUSSION}

\section{Improving Yield by Fermentation of Kaffir Lime}

In the aerobic fermentation process using tempeh yeast that contains Rhizopus sp., lignin and hemicellulose were degraded, and the crystalline structure of the cellulose was then opened, facilitating evaporation of oil bound in vacuoles, glands internal, and external oil.

Rhizopus sp. has a vegetative cell shape in the form of yarn called hyphae. During fermentation process, hyphae penetrate the leaf tissue and release enzymes that have a function to degrade compounds contained within cell walls such as carbohydrates, fats, and proteins. In addition, Rhizopus sp. also produces cellulase and pectinase enzymes which are biocatalysts in cellulose and pectin degradation on plant cell walls (León and Montesano, 2013).

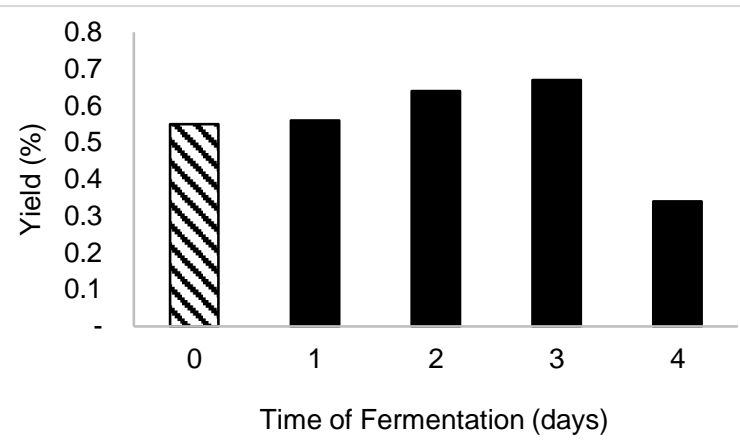

NN without fermentation $\square$ with fermentation

Fig. 2 Effect of fermentation time on yield of kaffir lime oil.

Fig. 2 shows the yield of kaffir lime oil for day 0 (distillation without fermentation pretreatment) and distillation with fermentation for 1,2 , 3,4 days were $0.55 \%, 0.56 \%, 0.64 \%, 0.67 \%$, and $0.34 \%$, respectively.

Rhizopus sp. growth can be observed visually as shown in Fig. 3. The presence of white hyphae on the surface of kaffir lime leavesaffected the yield of Kaffir lime oil which can be seen in Fig. 2.

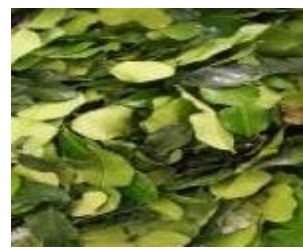

A

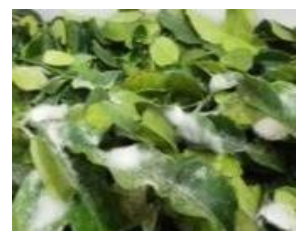

C

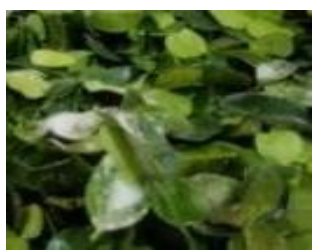

B

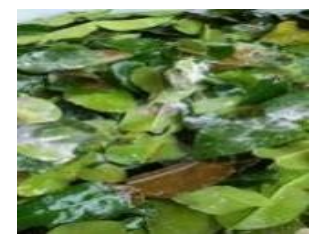

D
Fig. 3 Hyphae on the surface of kaffir lime leaves (a) fermentation at day 1 (b) fermentation at day 2 (c) fermentation at day 3 (d) fermentation at day 4.

The most optimum yield occurs on day 3 of fermentation. This is because degradation process of Rhizopus sp. occurred during fermentation process as proved by SEM images in Fig. 4. This degradation process led to the oil evaporation.

The yield product increases by $22 \%$ compared to day 0 of fermentation. On day 1 of fermentation, Rhizopus $s p$. was still adapting to its environmental conditions as well as the occurrence of enzyme synthesis. On day 2 of fermentation, it is estimated that the Rhizopus $s p$. cells wall degradation processes occurred, but on day 4 of fermentation there is a decrease in yield because of the degradation of the cell wall, causing evaporation of volatile oil bound in the internal 
and external oil glands, which then was carried by air when fermentation took place before the distillation.

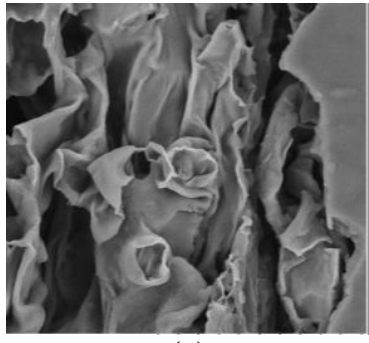

(a)

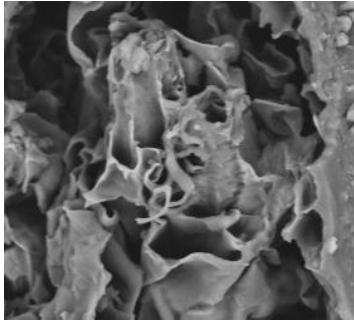

(b)
Fig. 4 SEM of Kaffir Lime Leave (a) before fermentation (b) after fermentation.

\section{Effect of fermentation to the composition of kaffir lime essentials oils}

An analysis conducted using GC-MS shows that after pretreatment fermentation $0,1,2,3$, and 4 days, the essential oil (OE) of the leaves of Kaffir Lime (Citrus hystric DC) composed of 26 components. The major constituents are shown in Table 1.

Table 1 constituents percentages identified in essential oils of kaffir lime.

\begin{tabular}{|c|c|c|c|c|c|c|}
\hline \multirow{2}{*}{ Compound } & \multirow{2}{*}{$\begin{array}{l}\text { RT } \\
\text { (min) }\end{array}$} & \multicolumn{5}{|c|}{ Time of Fermentation } \\
\hline & & $\begin{array}{l}0 \text { day } \\
(\%)\end{array}$ & $\begin{array}{l}1 \text { day } \\
(\%)\end{array}$ & $\begin{array}{l}2 \\
\text { days } \\
(\%)\end{array}$ & $\begin{array}{l}3 \\
\text { days } \\
(\%)\end{array}$ & $\begin{array}{l}4 \\
\text { days } \\
(\%)\end{array}$ \\
\hline Cis-Ocimene & 3.15 & - & - & 0.07 & - & - \\
\hline$\beta$-Pinene & 3.25 & - & - & 0.04 & - & - \\
\hline L-Linalool & 3.44 & 1.61 & - & 1.55 & - & - \\
\hline Linalool & 3.52 & - & 1.9 & & 1.77 & 1.17 \\
\hline Citronellal & 4.10 & 85.15 & 88.01 & 88.8 & 87.93 & 75.96 \\
\hline Citronellol & 4.94 & 1.39 & - & 0.07 & 0.90 & 6.91 \\
\hline L-Citronellol & 5.6 & - & 0.19 & 0.35 & 0.48 & - \\
\hline $\begin{array}{l}\text { 6-Octen-1-ol, 3,7- } \\
\text { dimethyl- }\end{array}$ & 5.68 & - & 0.47 & 0.78 & 0.19 & 0.76 \\
\hline$\beta$-Citronellol & 5.79 & 0.13 & - & - & - & - \\
\hline Citronellyl Acetate & 6.31 & 0.39 & - & - & 0.39 & 1.8 \\
\hline Citronellyl Propionate & 6.37 & 0.85 & - & - & - & 0.81 \\
\hline a-Humulene & 7.31 & 0.18 & - & 0.27 & 0.29 & 0.25 \\
\hline Isopulegol & 8 & - & - & 0.16 & & 0.15 \\
\hline Delta.-cadinene & 8.39 & 0.2 & - & 0.26 & 0.18 & 0.23 \\
\hline Beta.-Bisabolene & 8.55 & - & 0.34 & - & - & 0.13 \\
\hline $\begin{array}{l}\text { Geranyl Linalool } \\
\text { Isomer B }\end{array}$ & 8.71 & 0.02 & - & - & - & - \\
\hline Caryophyllene Oxide & 9.05 & 0.16 & - & - & - & - \\
\hline Trans-Caryophyllene & 9.12 & 0.26 & - & - & - & 0.05 \\
\hline B-Caryophyllene & 9.29 & 0.07 & - & 1.3 & 1.00 & 0.79 \\
\hline $\begin{array}{l}\text { Alpha.-Trans- } \\
\text { Sequicyclogeraniol }\end{array}$ & 9.49 & 0.28 & - & - & - & - \\
\hline L-B-Pinene & 9.61 & - & - & - & 0.22 & - \\
\hline 2-B-Pinene & 9.65 & - & - & - & 0.41 & - \\
\hline $\begin{array}{l}\text { Caryophylla-3,8(13)- } \\
\text { Dien-5.Alpha.-O }\end{array}$ & 10.22 & - & - & - & 0.20 & - \\
\hline Trans-Geraniol & 12.14 & - & - & 0.02 & - & 0.05 \\
\hline Camphene & 12.29 & 0.14 & - & - & - & - \\
\hline $\begin{array}{l}\text { 3-Octyne, 2,2,7- } \\
\text { Trimethyl- }\end{array}$ & 13.54 & 0.27 & - & 0.03 & 0.46 & 0.17 \\
\hline Total Identified & & 91.1 & 90.91 & 93.59 & 94.42 & 89.23 \\
\hline Others & & 8.9 & 9.09 & 6.41 & 5.58 & 10.77 \\
\hline
\end{tabular}

Table 1 shows that time of fermentation can cause variation in the composition of kaffir lime oil. This is due to activity enzymes from tempeh yeast such as cellulose, pectinase, and protease which cause biotransformation process that converts one compound to another, causing isomerization and cyclization reactions (Hernandez, 2017). The major compounds among the constituents found were citronellal, citronellol, linalool, $\beta$-Caryophyllene, and Citronellyl Acetate. Based on the local flavor and fragrant industry, minimum standard for quality kaffir lime oil represented by major compound constituent, Citronellal $65 \%$, citronellol $1.9 \%$, linalool $3.5 \%$, $\beta$ - Caryophyllene $0.2 \%$, and Citronellyl Acetate $1 \%$. The second day fermentation showed high content of citronellal but citronellol, $\beta$-Caryophyllene and citronellyl acetate were not identified. Thus, it can be concluded that day 3 of fermentation with major compound, citronellal $87 \%$, citronellol $0,9 \%$, linalool $1.77 \%$, $\beta$ - Caryophyllene $1 \%$, and citronellyl acetate $0.39 \%$ is the most optimal fermentation time because of complete major compound were clearly found in kaffir lime oil. Small amount compounds such as $\beta$-Citronellol, $\beta$-Pinene, $\beta$-Bisabolene Caryophyllene Oxide disappear because of hydrolysis, oxidation or reaction esterification (Boelens, 1997).

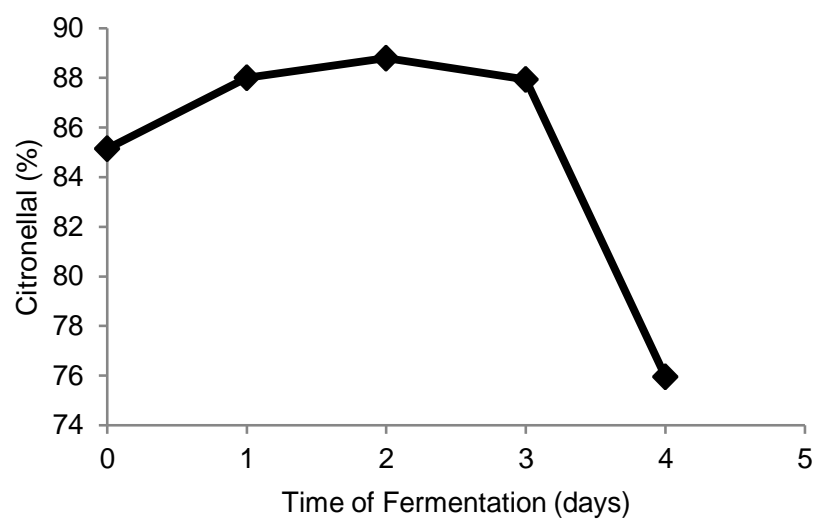

Fig. 5 Effect of fermentation on Citronellal compound in kaffir lime oil.

Citronellal is the main component of kaffir lime oil which has many uses, especially perfume and cosmetics industry (Khasanah et al., 2015) and has antioxidant and antibacterial activities (Susilo, 2016). Figure 5 shows that fermentation with tempeh yeast can increase citronellal content kaffir lime oil. This identified the existence of a biotransformation process by Rhizopus yang resulting in a cyclization reaction of monoterpenes (Citronellal) followed by secondary reactions to citronellol. The change of citronellal to citronellol is shown in the Figure 6 (Baser and Buchbauer, 2010). It also can be proven by the increasing levels of citronellol as shown in Table 1 that the amount of citronellol increased almost 6 times from day 3 to day 4 .

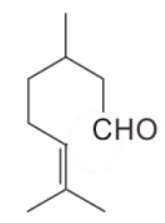

Citronellal

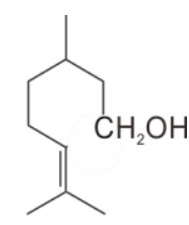

Citronellol
Fig. 6 Biotransformation of Citronellal to Citronellol by microorganism (Baser and Buchbauer, 2010).

\section{CONCLUSION}

Fermentation using tempeh yeast has successfully increased yield of kaffir Lime oil to $22 \%$ higher than that without fermentation. Besides, the quality of kaffir lime oil improved, which is showed by an increase in content of citronellal in the kaffir lime oil by $35 \%$ compared to local industry standard. The optimum fermentation time is on the day 3 resulting in the highest yield of $0.67 \%$, in which the major compounds are Citronellal (87.92 \%), $\beta$-Caryophyllene (1\%), Citronellol (0.90\%), Citronellyl Acetate (0.39\%). 


\section{ACKNOWLEDGEMENT}

On this occasion, thank you to: (1) Chemical Engineering Department, Brawijaya University; (2) Group Researcher in Laboratory of Bioprocess Engineering; (3) Group Researcher in Institut Atsiri, Brawijaya University.

\section{REFERENCES}

Axnessy, R., Maimunah H. P., Sukardi, Arie F. B., 2014. Application of PEF (Pulsed Electric Field) on Extraction of Essential Oil of Kaffir Lime Leaves with Water and Steam Distillation Method, Bachelor Thesis, Brawijaya University, Malang, Indonesia.

Baser, K. H. C., Buchbauer, G., 2010. Handbook of Essential Oil: Science, Technology and Applications, CRC Press, Boca Raton, Florida, USA.

Boelens, M. H, 1997. Production, Chemistry and Sensory Properties of Natural Isolates, Chapter In: Karl A.D. Swift (Ed.), Flavours and Fragrances, The Royal Society of Chemistry, United Kingdom, 77-79.

Endarta, 2008. The Effect of Drying Time and Water Content in Citrus Hystrix DC Raw Materials to the Essential Oils Yield on Separation Process with Water and Steam Distillators, Thesis, Gadjah Mada University, Yogyakarta, Indonesia.

Imron, M., 2008. The Effect of Measuring Size in Citrus Hystrix DC Raw Materials to the Essential Oils Yield on Separation Process with Water and Steam Distillators, Thesis, Gadjah Mada University, Yogyakarta, Indonesia.

Hernandez, L. H., Christina R. T., Hector A. R., Juan A. V., Miguel A. G., Raul R.H., Cristobal N.A. 2017. Rhizopus Oryzae-Ancient Microbial Resource with Importance in Modern Food Industry. Colombia; Faculty of Engineering School of Food Engineering.

Khasanah, L. U., Kawiji, Utami, R., Aji, Y. M., 2015. The effect of preliminary treatment on the quality characteristics of essential oils of citrus hystrix DC leaves, Jurnal Aplikasi Teknologi Pangan, 4 (2) 48-55.

Khasanah, L. U., Rohula, U., Baskara K. A., Nugraheni, A. E., 2014. The effect of preliminary treatment of solid fermentation and liquid fermentation on the yield and quality characteristics of essential oils of cinnamon leaves, Agritech, 34 (1), 36-42.

Ketaren, S., 1993. Introduction of Essential Oil Volume II, Balai Pustaka, Jakarta, Indonesia.

Laurita, L., Herawati, M. M., 2016. The Effect of Solid Fermentation Time on Characteristics of Physical Quality and Results of Yield of Essential Oi Sweet Orange Skin Waste (Citrus sinesnsis var. Baby Pacitan). Proseding Konser Karya Ilmiah Vol 2, Agustus 2016, Universitas Kristen Setya Wacana, Salatiga, 43-50.

Leon, I. P., Montesono, M., 2013. Activation of deense mechanism against pathogens in mosses and fowering plants. International Journal of Molecular Scince, 14, 3178-3200.

Lopez-Romero, J. C., Gonzales-Rios, H., Borges, A., Simoes, M., 2015 Antibacterial effects and mode of action of selected essential oils components against escherichia coli and staphylococcus aureus, EvidenceBased Complementary and Alternative Medicine 2015, Article ID 795435 9 pages.

Lu, Y., Khoo, T. J., Wiart, C., 2014. Antioxidant activity determination of citronellal and crude extract of cymbopogon citratus by 3 different methods, Pharmacology \& Pharmacy, 5(4), 395-400.

Mayasari, D., Jayuska, A., Wibowo, M. A., 2013. Effect of time variation and sample size on the composition of essential oils from kaffir lime leaves (Citrus hystrix DC), Jurnal Kimia Khatulistiwa, 2(2), 74-77.

Masutti, D. C., Borgognone, A., Setti, L., 2012. Production of Enzymes from Rice Husk and Wheat Star in Solid State Fermentation, Chemical Engineering Transactions, 27, 133-138.

Raharjo, S. J., Retnowati, R., 2012. Yield increasing of patchouli oils of result steam distillation of patchouli leaf of dewaxing, fermentation, and drying process, Journal Basic Science and Technology, 1(3), 12-18.

Ririn, M., 2010. Comparison of essential oil yields on kaffir lime leaves (citri hystricis folium) Dry and wet with water distillation, Bachelor Thesis, Poltekkes Bakti Mulia, Sukoharjo, Indonesia.

Sato, A., Asano K., 2011. The chemical composition of citrus hystrix DC, Journal of Essential oil Research, 2 (4), 179-183.

Susilo, J., 2016. Farming of Kaffir Lime, Tunas Abadi, Surabaya, Indonesia.

Zuorro, A., Lavecchia, R., Medici, F., Piga, L., 2014. Use of cell wall degrading enzymes for the production of high-quality functional products from tomato processing waste, Chemical Engineering Transactions, 38, 355-260. 